\title{
UN CASO DE CÁSCARA DE NUEZ \\ La Contribución de la Conservación Arqueológica para la Preservación de Artefactos de Turquesa de Alta Vista, Zacatecas, México
}

\author{
A NUTSHELL CASE \\ The Contribution of Archaeological Conservation to the \\ Preservation and Research of Turquoise Artefacts from the Alta \\ Vista Archaeological Site, Zacatecas, Mexico
}

\section{Isabel Medina González ${ }^{1}$}

ismedin@gmail.com

\section{RESUMEN}

Durante noviembre de 2009, un grupo de ENCRyM-INAH tuvo la oportunidad de participar en la conservación de artefactos turquesas exhibidos en el Museo de Sitio del Sitio Arqueológico de Alta Vista, Zacatecas. Durante el diagnóstico de esta colección se descubrieron aspectos clave con respecto al proceso de fabricación, deterioro y conservación de cada artefacto. Esta información era esencial para el proceso de toma de decisiones y la intervención para preservar los valores de cada elemento turquesa. Este texto se centra en el análisis de estos logros de investigación y las preguntas que se derivan de ello.

Palabras clave: Turquesa, conservación, deterioro, restauración.

1 Restauradora, Escuela Nacional de Conservación, Restauración y Museografía, Instituto Nacional de Antropología e Historia, México. 


\section{ABSTRACT}

During November 2009, a group from ENCRyM-INAH had the opportunity to participate in the conservation of turquoise artifacts exhibited at the Museo de Sitio of the Archaeological Site of Alta Vista, Zacatecas. During the diagnosis of this collection, the restorer's close and detailed observations uncovered key aspects regarding the process of manufacture, deterioration, and conservation of each artifact. This information was essential for the decision-making process and intervention for preserving the values of each turquoise item. This text focuses on the analysis of these research achievements and the questions that derived from them.

Keywords: Turquoise, conservation, deterioration, restoration.

\section{RESEARCH CONTEXT}

In 2009, the National School of Conservation, Restoration and Museography (ENCRyM), an academic entity of the National Institute of Anthropology and History (INAH) --directed by restorer Liliana Giorguli--, agreed with the Alta Vista Archaeological Project -under the leadership of archaeologist Baudelina García Uranga-- to undertake a conservation project (MEDINA, 2009a). This initiative coordinated by Isabel Medina-González and Rest. Adriana Sanroman, professors of the Seminar on Archaeological Conservation of ENCRyM-INAH - aimed three objectives: 1) to enrich student's knowledge and skills in the treatment of archaeological materials on site within a real institutional work scenario; 2) to consolidate ENCRyM's role in supporting the fulfilment of INAH's responsibilities regarding the research, conservation and dissemination of Mexican cultural heritage, and in particular, those efforts that have been carried out for a long time for the preservation of Alta Vista Archaeological Site (AVAS); and, 3) to increase 
interdisciplinary cooperation between conservators and archaeologists starting from the educational foundation to the important complementation of academic and executive areas of the INAH (MEDINA, 2009a).

This project initially focused exclusively on the Picacho Pelón Relief, an architectural-sculptural element of great beauty, technological complexity and iconographic importance, which was originally was part of the decoration that adorned the cornice of the Temple of the Sun, Astronomers Complex, AVAS (MEDINA, 2009A; MEDINA AND GARCÍA, 2010).

After its discovery within the archaeological debris at the beginning of the 1990s, the Picacho Pelón Relief- an element formed by adobe bricks covered with polychrome plaster-- remained in situ for almost 20 years with a view to a final destination that would enable its preservation and display (MEDINA, 2009A; 2009b). Yet, it was only with the inauguration of Alta Vista Archaeological Museum (AVAM) in 1997 and following the instructions and criteria stated in an archaeological conservation diagnosis (MEDINA, 2009a), that archaeologists and conservators decided that the Picacho Pelón Relief would be the object of a process of integrated conservation that comprise phases of recovery, relocation, stabilization, restoration and museum interpretation, all which would take place during a 3-week field trip at the AVAS in November 2009 (MEDINA, 2009a; 2009b). 
It was precisely during of preparation stages of this enterprise that its scope was extended to the archaeological collection at currently at display in the AVAM (AVECILLA et al. 2009; MEDINA AND SANROMAN, 2009; MEDINA, 2009a; SANROMAN et al., 2011). The reasons for this decision were many-fold, including the conservation needs of many artefacts, which had not been properly treated by restorers since their inclusion in the display arrangement. Furthermore, we realised that intervention on this collection would enhance both research prospects and the teaching-learning experiences of the project, since the AVAM collection is unique within Mesoamerican archaeology in terms of material richness, formal variety, and data potential.

Ninety-one artefacts made of different materials — bone, shell, stone and various organic materials - were selected and intervened in 2009 (MEDINA AND SANROMAN, 2009; SANROMAN et al., 2011). Among these, objects made of bluish-green stone tesserae - here and forward call by their generic name "turquoise" - were noteworthy due to their great beauty and amazing complexity.

Following a conventional methodology for archaeological conservation, each one of these elements underwent a series of processes: recording, value assessment, diagnosis, proposal, decision-making and direct intervention, and in some cases, optimization of museum display. (MEDINA AND SANROMAN, 2009; SANROMAN et al., 2011). During these actions, new observations on the materials came to light; these findings, hitherto unpublished, have in turned helped to revisit questions about the turquoise phenomenon in the context of the Suchil Culture. This 
paper presents the background, development, results and contributions of this experience in order to pose a series of reflections and perspectives on the rationality of conservation and its epistemological contribution to archaeology.

\section{THE TURQUOISE ASSEMBLAGE}

AVAM exhibits a collection of turquoise artefacts composed by 14 single and composite elements: twelve mosaic objects, a beaded necklace and a set of circular tesserae without a base, respectively (Figures 1-3). The discovery of turquoise materials, particularly made of tesserae, in the AVAS certainly extends to the excavations carried out by Gamio in 1910 (KELLEY AND KELLEY, 1971; MEDINA AND GARCÍA, 2010); however, those nowadays in display at AVAM are largely the result of three different field-seasons of the Alta Vista Archaeological Project that took place during the 1970s under the direction of Doctor Charles Kelley, an academic of Southern Illinois University. 


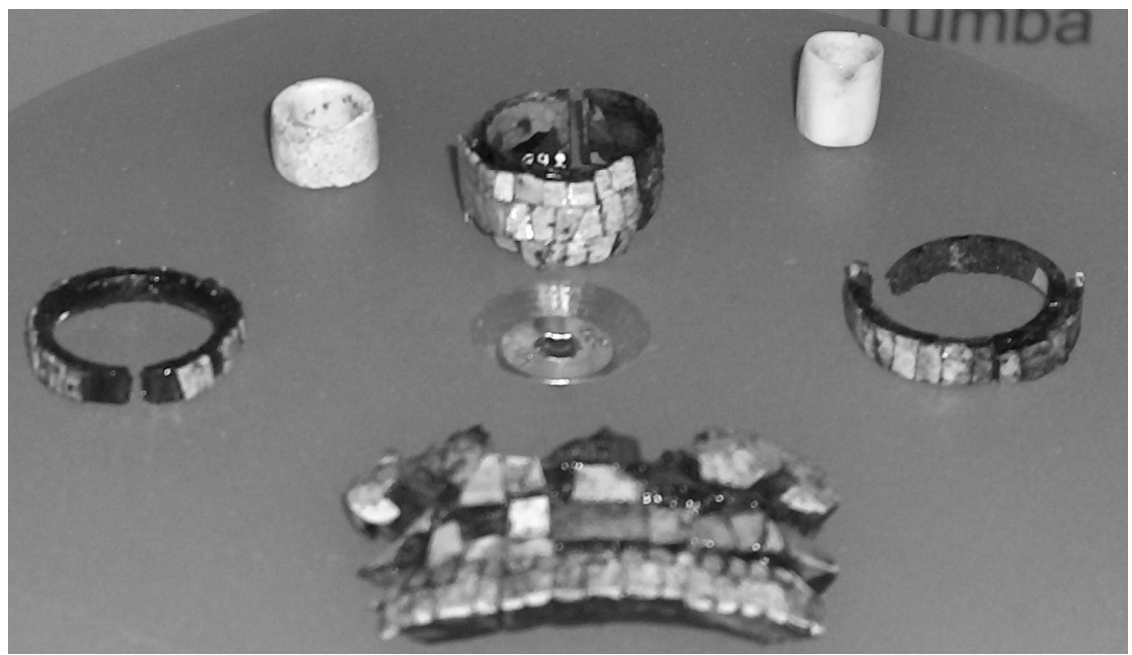

Figure 1. Turquoise Inlaid Pre-Columbian Jewelry, Alta Vista Museum, Zacatecas (Courtesy: ENCRyM-INAH).
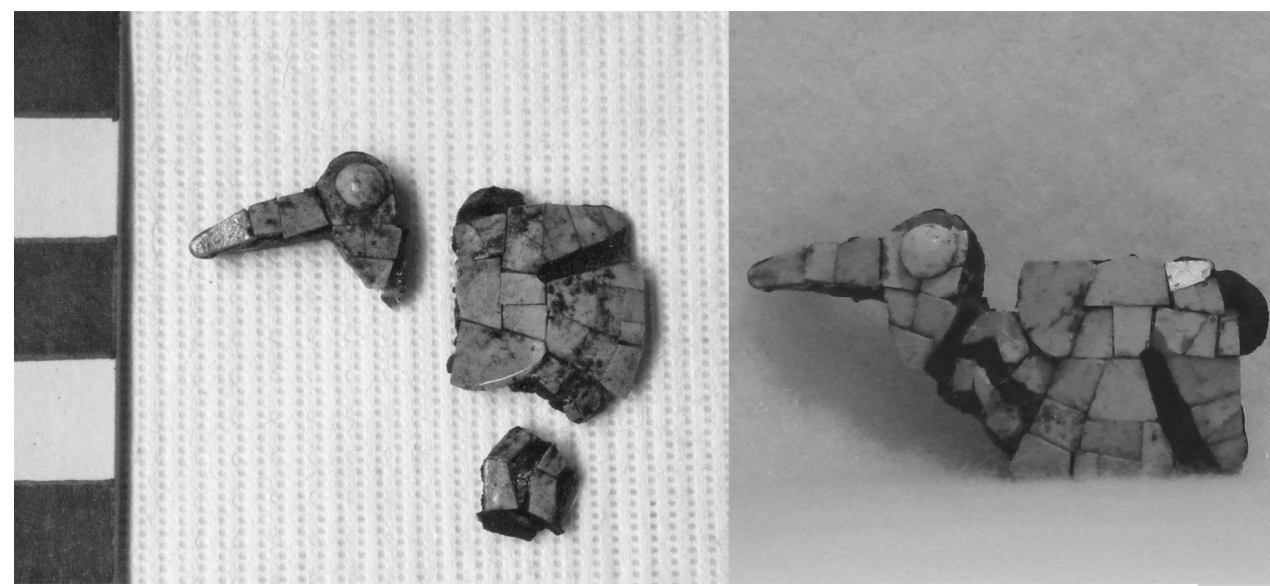

Figure 2. Conservation of Turquoise Inlaid Artefact, Alta Vista Museum, Zacatecas (Courtesy: ENCRyM-INAH).

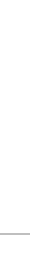

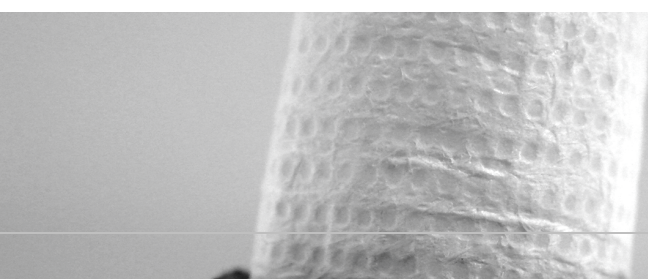



ENCRyM-INAH).

Information about the archaeological work carried out those years in AVAS is today limited in Mexico, where there are only succinct reports translated to Spanish language (KELLEY AND KELLEY, 1971; KELLEY, 1974; 1975). Yet, on the basis of them we conclude that a large part of the AVAM "turquoise" collection artefacts was found in a series of ritual contexts -burials and offerings- that were excavated in the Hall of Columns, in the Southeast Platform of the Southeast Square and in the Sun Pyramid's underground room (Structure 2B). Noteworthy is the archaeological context in which many of these artefacts were found and much as their associations: 
“ [...] the skeletal remains of three important people [were] buried on different occasions. Among the objects that were recovered from the accompanying offerings are turquoise and/or malachite mosaics, nutshell rings, turquoise beaded necklaces, wooden rings with turquoise bands, a batch of small flakes of obsidian and another batch of flint, a fragment of a mottled obsidian knife, a polished black ceramic plate and fragments of rotten gourds. In the western corner, an "authority baton" (a broken votive arrow shaft) and a perforated shell trumpet were found." (KELLEY, 1970; MEDINA AND GARCÍA, 2010: 97).

This is most sophisticated funerary complex discovered in AVAS to date, since it comprised many prestigious objects such as marine materials brought form faraway places, delicate jewellery made of organic materials, as well as the most opulent mortuary trousseau in turquoise of Suchil Culture.

The interpretation on the archaeological significance of these "turquoise" materials, as well as their contexts, which has required the examination of Kelley's large body of archaeological documentation, is currently being carried out by the archaeologists Baudelina Uranga and José Humberto Medina. Consequently, here I will only refer to the contributions achieved during the process of archaeological conservation.

\section{METHODOLOGY AND DEVELOPMENT}


The conservation process of the AVAM turquoise collection followed a strict methodology, as follows:

A. Recording. This process began by producing a textual, graphic and photographic inventory of the artefacts at their current location: the display cabinets of AVAM main exhibition gallery. This layout aimed to ensure rigorous control during dismounting, laboratory management and, re-mounting the artefacts at the end of their intervention;

B. Documentation. This initiated by careful observing each artefact, whose materiality was considered a source of information on its own right. Subsequently, our observations were compared with the data provided by inventory drafted by García Uranga and Medina González (2009). Examination of archaeological reports was later complemented with interviews to archaeologists and museum personnel in order to obtain data on regarding the objects' significance, technology and history. Thus, different sources served to complement and problematize our knowledge, which in turn aided to both formulate new questions and, when necessary, redirect the subsequent project actions. Hence, as result of the documentation, we divided two groups of "turquoise" artefacts: on the one hand, a necklace and dozens of round tiles that would undergo intervention within the display cabinets and, on the other hand, fifteen artefacts that would be treated in the laboratory. The latter were composite artefacts: turquoise tesserae mosaics superimposed on different types of bases including pyrite, shell, wood, and nut shells. The following table presents a summary on the typology, constituent materials and morphology of these artefacts. 
C. Significance Assessment. Significance assessment is an essential phase in modern-day conservation, since over the last two decades the guiding principle of this discipline has change to propose that we must identify, preserve, maintain and transmit all values derived from the materiality and inmateriality of cultural heritage to present and future generations (see Australian/ICOMOS 1991, KERR, 1991). To be true, archaeological conservation tends to give great importance to the preservation of the artefact's informative nature, which relies on all its historical, aesthetic, technological and functional aspects. Noteworthy is the idea that archaeological value not only constitutes the actual capacity of material culture to inform us about the past, but also its potential to act as evidence for archaeological interpretation.

It should be pointed out that although archaeological records initially stated that the rings with bands of turquoise were made of wood, careful observation, as well as discussion between archaeologists and conservators led to conclude that that their base was made of cross-sections of pecan shell (Carya illioniosis). 


\begin{tabular}{|c|c|c|c|c|}
\hline Quantity & Type & Material & $\begin{array}{l}\text { Inventory Number/ Display Cabinet/ } \\
\text { Description/ Figure }\end{array}$ & $\begin{array}{l}\text { Inventory or Catalogue } \\
\text { No./Display Cabinet } \\
\text { and Serial No. } \\
\text { ENCRyM. }\end{array}$ \\
\hline 1 & Disk & $\begin{array}{l}\text { Wooden } \\
\text { Base with } \\
\text { Pyrite and } \\
\text { Turquoise } \\
\text { Tesserae } \\
\text { Mosaics. }\end{array}$ & $\begin{array}{l}\text { Fragment of circular element, consisting of a } \\
\text { wooden base on which there is a star/asterisk of } \\
9 \text { projections with square tips made of } \\
\text { quadrangular turquoise tesserae and a semi- } \\
\text { spherical piece made from the same material in } \\
\text { the centre, whose negative background spaces } \\
\text { are decorated with fragments of pyrite, } \\
\text { highlighting a circular tesserae. }\end{array}$ & $\begin{array}{cc}\text { MAV 7/2009 } & \text { V12 } \\
\text { ENCRyM } 2009 \text { V12C1 }\end{array}$ \\
\hline 1 & Decoration & $\begin{array}{l}\text { Original } \\
\text { Base } \\
\text { missing, } \\
\text { Turquoise } \\
\text { Tesserae } \\
\end{array}$ & $\begin{array}{l}\text { Element without original base made of } \\
\text { quadrangular and triangular turquoise mosaics, } \\
\text { which form the shape of a praying mantis, } \\
\text { whose eyes are made of semi-spherical pieces. }\end{array}$ & $\begin{array}{cc}10-637673 & \text { V6 } \\
\text { ENCRyM2009 V6A1. }\end{array}$ \\
\hline 2 & Earring & $\begin{array}{l}\text { Shell Base } \\
\text { with } \\
\text { Turquoise } \\
\text { Tesserae } \\
\end{array}$ & $\begin{array}{l}\text { Quadrangular elements made with white/pink } \\
\text { shells with precise application of quadrangular } \\
\text { tesserae. }\end{array}$ & $\begin{array}{c}\text { 10-637813 V13 } \\
\text { ENCRyM } 2009 \text { V13A3 }\end{array}$ \\
\hline \multirow[t]{3}{*}{3} & \multirow[t]{3}{*}{ Pendant } & \multirow[t]{3}{*}{$\begin{array}{l}\text { Wooden } \\
\text { Base with } \\
\text { Turquoise } \\
\text { Tesserae }\end{array}$} & Two fragments with turquoise tesserae & $\begin{array}{c}\text { MAV 9/2009 and } \\
\text { MAV 8/2008 V13 } \\
\text { ENCRyM 2009 V13 } \\
\text { A1 and A2 } \\
\end{array}$ \\
\hline & & & $\begin{array}{l}\text { Complete element in the shape of a bird's } \\
\text { profile }\end{array}$ & $\begin{array}{ll}\text { V13 ENCRyM } 2009 \\
\text { V13A4 }\end{array}$ \\
\hline & & & $\begin{array}{c}\text { Complete element in an abstract shape of a } \\
\text { butterfly }\end{array}$ & $\begin{array}{c}\text { MAV 6/2009 V112 } \\
\text { ENCRyM } 2009 \text { V12A4 }\end{array}$ \\
\hline 10 & Ring & $\begin{array}{l}\text { Nutshell } \\
\text { Base with } \\
\text { single- or } \\
\text { double-line } \\
\text { Turquoise } \\
\text { Tesserae }\end{array}$ & $\begin{array}{l}\text { Nutshell base in the shape of a ring with a } \\
\text { natural opening in different thicknesses to } \\
\text { include a triple band ( } 1 \text { element), double band ( } 3 \\
\text { elements) and single band of turquoise tesserae } \\
\text { (6 elements) }\end{array}$ & $\begin{array}{l}\text { 10-637764 to } 10- \\
\text { 637770, V12 } \\
\text { ENCRYM V12D1 to } \\
\text { D7 }\end{array}$ \\
\hline
\end{tabular}

Table 1. General List of Turquoise Composite Artefacts in the Alta Vista Museum, Zacatecas. 


\section{General List of Turquoise Composite Artefacts in the Alta Vista Museum, Zacatecas}

Value assessment of AVAM's turquoise collection was carried out through careful documentation, research of relevant body of literature and, a dialogue amongst those directly involved/interested in its preservation. This exercise, which clarified explicit parameters regarding the significance of the artefacts both under the current state of knowledge in archaeological material and in view of possible lines of research, concluded that:

First, AVAM "turquoise" artefacts are unique in the pre-Hispanic cultural heritage of the territories that today occupy Mexico and the southwest region of the United States. It is estimated that over a million turquoise artefacts have been discovered in various Mesoamerican sites (Weigand 1968; Harbottle and Weigand 1992); however, there are few series with such a formal and material variability, that were discovered in a single archaeological site and that were subjected to a rigorous excavation process. In fact, the richness and diversity of the AVAM collection is only comparable to the findings made in Pueblo Bonito, New Mexico (PEPPER, 1905). Second, another relevant value of the AVAM collection is related to the information associated to its archaeological context: as previously stated, the archaeological record suggests that during the pre-Hispanic period some of the turquoise artefacts fulfilled a ritual vocation. To be true, there is still much to be investigated on the archaeological significance of AVAM turquoise collection, particularly on those artefacts discovered in the Pyramid of the Sun as part of the 
most complex and magnificent funerary complex of the Suchil Culture found to date.

Third, in comparison with the most famous collections of pre-Columbian turquoise displayed in different museums in Mexico and the rest of the world --which mainly consist of masks, disks and other ornamental pieces, the AVAM collection is predominantly conformed by funerary jewellery. This category offers a new field of research not only as far as artefact typologies and functionality, but also regarding and largely understudied topic: funeral attire in Northern Mesoamerica (e.g. FILLOY, 2010).

Fourth: the AVAM collection is outstanding for its research potential as far as origin and mining distribution are concerned: on the one hand, the artefacts were found in the Chalchihuites region, a territory where more than 750 "cultural" turquoise mines have been recorded. In fact, Weigand (1993:318-322) suggests that two important mining periods took place around A.D. 350 A.D. and in A.D. 800 in the Chachihuites area, a region that became an strategic enclave for the northern land trade route towards the "chemical" turquoise mines situated in the southeast region of present-day United States (WEIGAND, 1978: 69). Furthermore, it is largely accepted that "chemical" turquoise appeared in Alta Vista around A.D. 650, a material that according to Weigand (1993: 252) came from distant mines, namely from Los Cerillos, $1500 \mathrm{~km}$ away, and from Tyrone, $1200 \mathrm{~km}$ away, both in New Mexico. Since the AVAS objects come from contexts dating to the Alta Vista period, which Kelley (1974) dated between A.D. 300.500, we can pose interest 
questions regarding the collection's nature, provenance and archaeological significance. For instance, we need to determine whether the artefacts were manufactured with local "cultural" turquoise, by exported "chemical" turquoise, or a mixture of both. This represents an opportunity to analyze the systems of extraction, procurement and mining trade that were of great relevance for the development of pre-Columbian America during the Classical period.

Fifth: the collection of turquoise artefacts that we are dealing with are of extraordinary importance for the technological study, not only for their particular characteristics in terms of bases, assembly and design - which I will refer to later but also because they were found at a site where one of the biggest turquoisecarving workshops in Mesoamerica can be found (WEIGAND, 1993: 256, 293, $337)$.

As Melgar (2010) points out, the interpretation of the turquoise phenomenon requires a second reading, which takes into consideration the sites, workshops and consumers since the place where they are obtained does not necessarily indicate the place where the piece is produced or manufactured. In the case of Alta Vista, it is key to study the manufacturing details, since we have already mentioned Chalchihuites does not only have a strategic location as an intermediary point on a trade route which joined the indigenous populations of central Mexico - including Teotihuacan - to those of New Mexico during the Mesoamerican Classical period, but also because of the participation of the inhabitants from Chalchihuites on this 
trade route, presumably involving local manufacture, an activity which has not been studied in depth in relation to the existence of a local, traditional style and the cultural development of the Suchil region.

In particular, it is important to mention that the technological study not only represents an opportunity for the experimental archaeology analysis of traces that remain on the turquoise tesserae, derived from the use of particular tools during production that have been identified as pertaining to the region of Chalchihuites (MELGAR, 2010), but also of other complementary phases of the manufacturing cycle. A technological aspect worth mentioning is that the tesserae of most of the MUSZAV's artefacts are arranged in "assembly systems", which raises questions on three themes: bases - wooden and walnut shell, types of adhesives used possibly resins, and types of assembly, topics which I will return to later.

Sixth: being pieces of jewellery and therefore ornamental, the manufacture of the turquoise pieces from the AVAM involved artistic considerations, which went into the design of the artefact, the choice of bases, the selection of different tones and sheens of the blue-green stone to make the tesserae, and the option of types of assembly. The combination of these factors, which were at stake for the achievement of artistic effects of great complexity and beauty, combining geometry, colour and sheen, provide aesthetic and artistic values, which require more in-depth research regarding their differences and similarities with other preColumbian turquoise collections. 
Seventh: an additional aspect of the value assessment of the AVAM turquoise collection refers to its use and consumption, which as we have already mentioned is undoubtedly the most refined example of lavish funeral jewellery in the Suchil Culture and in the pre-Hispanic Zacatecas region, and very possibly in the north of Mexico. As such, several of the objects - rings and earrings - were manufactured for the purpose of decorating the body. What is noteworthy here is the way in which the form and function are intimately linked, especially in two obvious characteristics: on the one hand, in the fasteners which are on the back of the earrings' wooden bases, and on the other hand, in the design of the ring derived from the cross-section of the pecan shell which makes up the rings.

Eighth: in addition, the collection is a representative series; that is to say, only a fraction, although undoubtedly exceptional, of the considerable number of turquoise fragments and elements discovered in Alta Vista during its long history of more than one hundred years of archaeology, are well-protected for their archaeological conservation research and intervention. These materials have been studied in a limited manner by archaeologists and conservators, which is why there is not much information published about them.

Ninth: the collection is also notable within the archaeological conservation field. No detailed information is available on the way they were extracted, but it seems that although a direct method was predominantly used, those involving the immersion/application of paraffin were prohibited. Everything seems to indicate that the pieces were generally found to be stable when they were extracted from the 
archaeological deposit, although the detachment of the tesserae led to the intervention in terms of restoration, a treatment that will be described later, in particular because of its consequences in the physical condition of the pieces. Alternatively, its didactic nature must be considered since it is the only series of materials from Alta Vista that is on public display after their museographic installation when the AVAM opened in 2003.

These nine value assessment parameters clarify not only why the pieces are relevant but also which conservation requirements must be complied with, particularly in terms of the effect of agents, an equation that was clarified through the diagnosis.

\section{Diagnosis}

The diagnosis of the AVAM turquoise pieces includes two steps: firstly, to study their physical condition based on both the observation of the artefact and on the analysis of informative sources and similar cases, a process resulting in an analysis of causality factors; and secondly, to evaluate previous variables with regard to their effect on values to determine the most significant tangible and intangible deterioration to the artefacts in terms of the area affected, severity and priority attention.

Thanks to the study of the physical condition of the pieces, a series of alterations were identified by type of artefact as summarized in the following table:

\section{Type}

Alterations Present 


\begin{tabular}{|c|c|}
\hline $\begin{array}{l}\text { Walnut Shell } \\
\text { Rings }\end{array}$ & $\begin{array}{l}\text { Base with localized disintegration but stable. } \\
\text { Discontinuity in the diameter of the ring base, coinciding with the } \\
\text { tesserae sequence. } \\
\text { General fragility in the adhesion of the tesserae, from one tile to another, } \\
\text { and with regards to the base. } \\
\text { Change in alignment of mosaic tesserae. } \\
\text { Alteration to colour of turquoise tesserae due to the presence of the } \\
\text { remains of synthetic film applied in an earlier intervention, which has } \\
\text { oxidized, becoming yellowish, and sediment remains are present. } \\
\text { Sediment accumulation. }\end{array}$ \\
\hline $\begin{array}{l}\text { Disks and } \\
\text { Pendants }\end{array}$ & $\begin{array}{l}\text { Wooden base with physical damage: localized disintegration in } 3 \\
\text { artefacts, in one of the pendants: fragmentation in } 3 \text { sections. } \\
\text { Coherence between the particles of the material. } \\
\text { In all the artefacts: } \\
\text { - Localized fractures in tesserae. } \\
\text { - Change to alignment of mosaic tesserae. } \\
\text { - Alteration to colour of turquoise tesserae due to the presence of } \\
\text { the remains of synthetic film applied in an earlier intervention, } \\
\text { which presents accumulated excess, widespread yellowish } \\
\text { oxidation and sediment remains. } \\
\text { - Sediment accumulation. } \\
\text { On the disk: Pyrite trace elements and with sediments. }\end{array}$ \\
\hline $\begin{array}{l}\text { Mosaics } \\
\text { without a } \\
\text { base }\end{array}$ & $\begin{array}{l}\text { Instability of the tesserae with respect to their paper support. } \\
\text { Superficial accumulation of residue. }\end{array}$ \\
\hline $\begin{array}{l}\text { Shell } \\
\text { Earrings }\end{array}$ & $\begin{array}{l}\text { Disintegrated base, with localized scaling and accumulation of dirt. } \\
\text { Alteration to the colour of turquoise tessarae due the presence of } \\
\text { synthetic film applied in an earlier intervention, which presents } \\
\text { accumulated excess, widespread yellowish oxidation and sediment } \\
\text { remains. }\end{array}$ \\
\hline
\end{tabular}


As a result of the process of the causality analysis, the following origins and mechanisms of alteration were determined:

A. Natural degradation of cellulosic material, accelerated by the natural loss of humidity during the prolonged period in an archaeological deposit.

B. Decomposition of original adhesive material through natural degradation during a prolonged period in an archaeological deposit.

C. Natural mineralization of pyrite through chemical corrosion in an archaeological deposit - in the case of the Disk.

D. Mechanical forces experienced by the artefacts in the deposit and during their extraction, possibly through the use of wax.

E. Inadequate earlier intervention in the use of synthetic polymers (possibly Paraloid B-72) as a consolidator, as well as in the procedure (immersion) and quality of execution.

F. Limited earlier intervention in the selection of paper as a substitute assembly base.

As a result of the analysis against the values, it was concluded that:

A. The large total of material changes to the bases and types of adhesives mean a risk to the materiality of the artefact, which serves as a vehicle for its current interpretation and future study.

B. The mineralization of pyrite produces a patina: which provides evidence of the antiquity of the pieces.

C. Limitations in extraction methods and earlier interventions with the use of synthetic polymers compromise the stability of the tessera mosaics, the way the design is understood, the observation of technological details and the appreciation of aesthetic qualities, which greatly affects its current and future value assessment.

D. A noteworthy observation regarding the walnut shell rings is that although the discontinuity of the diameter of the ring was detected 
as a physical alteration, it cannot be considered as deterioration, but rather an additional, technological value. Observations of the piece, confirmed by initial archaeological-experimental evidence suggests it is a natural opening derived from the cutting of the walnut shell and was apparently used to form a flexible adjustment mechanism, which was both beneficial to its use and commercial distribution. Therefore, this discontinuity should not be altered since it represents important archaeological evidence, which as far as I know, is unparalleled in the archaeological series of pre-Hispanic turquoise.

As it can be inferred, these determinations established specific necessities and limits for interventions in terms of conservation, which were especially important in the decision-making phase.

\section{Decision-making:}

The decision-making process for the pieces was not only based on the requirements derived from their value assessment and the necessities/limits identified during the diagnosis phase, but a series of normative criteria for professional practice were also considered:

A. Minimum intervention necessary depending on the severity, scale and obviousness of the alteration.

B. Compatibility of the materials used during the intervention with the constituent materials, or the materials used in earlier interventions to guarantee the stability of the piece.

C. Retreatability of the proposed treatments in order to obtain a balance regarding their current effectiveness and the possibilities of future treatment. 
D. Optimization of interpretation regarding the objects' current and future informative potential.

Based on the above, a technical procedure was determined, as shown in the following table:

\begin{tabular}{|c|c|c|}
\hline Process & Objective & Materials \\
\hline $\begin{array}{l}\text { Superficial } \\
\text { Cleaning }\end{array}$ & $\begin{array}{l}\text { Eliminate dust and } \\
\text { foreign particles } \\
\text { derived } \\
\text { previous } \\
\text { intervention from } \\
\text { the surface of the } \\
\text { materials, which } \\
\text { affect } \\
\text { appreciation of their } \\
\text { value. }\end{array}$ & $\begin{array}{l}\text { Mechanical action and use of solvents such as } \\
\text { water-alcohol 1:1, water-canasol at } 1 \% \text { and acetone. }\end{array}$ \\
\hline $\begin{array}{l}\text { Stabilizati } \\
\text { on of } \\
\text { Bases }\end{array}$ & $\begin{array}{l}\text { Restore the stability } \\
\text { of the pieces like the } \\
\text { alterations to the } \\
\text { bases and the } \\
\text { assembly of } \\
\text { turquoise tesserae } \\
\text { through differential } \\
\text { consolidation. }\end{array}$ & $\begin{array}{l}\text { Mosaics on shell bases: Localized consolidation with } \\
\text { Reconos } 110 \text { and } 220 \text { in broken areas. } \\
\text { Mosaics on wooden and walnut shell bases: due to a } \\
\text { previous application of synthetic polymers, localized } \\
\text { applications of Paraloid B- } 72 \text { at } 5 \% \text { in acetone and alcohol } \\
\text { were carried out. The fragmented bases will be put together } \\
\text { with Mowithal B } 60 \mathrm{H} \text { at } 15 \% \text { in acetone, with the partial } \\
\text { application of ceramic paste fillers, and where necessary } \\
\text { with Ren resin, with a previous intermediary layer of } \\
\text { Mowithal adhesive. } \\
\text { Mosaics without bases: veiled mosaics, detach intervention } \\
\text { base and substitute for transparent, acrylic plates with the } \\
\text { sequence and plan correction. }\end{array}$ \\
\hline $\begin{array}{l}\text { Restructuri } \\
\text { ng of }\end{array}$ & $\begin{array}{l}\text { Optimize the } \\
\text { sequence of the } \\
\text { mosaics and, where } \\
\text { necessary, restore }\end{array}$ & $\begin{array}{l}\text { Localized consolidation with Paraloid B- } 72 \text { to ensure they } \\
\text { are fixed to the base, carry out sequence plan correction } \\
\text { tasks. }\end{array}$ \\
\hline
\end{tabular}




\begin{tabular}{|l|l|l|}
\hline $\begin{array}{l}\text { mosaic } \\
\text { assembly }\end{array}$ & $\begin{array}{l}\text { the stability of the } \\
\text { base by localized } \\
\text { fixing or total } \\
\text { restoration. }\end{array}$ & $\begin{array}{l}\text { Detachment from the previous veiled sequence for } \\
\text { materials that require this, plus their reintegration, ensuring } \\
\text { the correct alignment of the tesserae, thus optimizing their } \\
\text { appreciation. }\end{array}$ \\
\hline $\begin{array}{l}\text { Chromatic } \\
\text { reintegrati } \\
\text { on }\end{array}$ & $\begin{array}{l}\text { Optimize the } \\
\text { appearance of the } \\
\text { interventions in } \\
\text { relation to the } \\
\text { integration of the } \\
\text { piece in order to } \\
\text { improve the } \\
\text { interpretation of its } \\
\text { values. }\end{array}$ & $\begin{array}{l}\text { Reintegration of colour and application of patinas with } \\
\text { painting and varnish in the treated areas. }\end{array}$ \\
\hline
\end{tabular}

Table 3. Materials.

\section{Implementation}

The interventions carried out followed the technical proposal exactly as had been previously planned, obtaining satisfactory results that have already been presented in forums and published (Sanroman, Avecilla, and Flores 2011; Avecilla and Flores 2010; Medina-González and Sanroman, 2011). This involved not only ensuring the physical preservation of the collection but also the optimization and potential in understanding the cultural value attached to each one of the pieces individually and the whole collection. The informative potential was particularly benefited in a reassessment of technological and aesthetic terms. The removal of previous interventions favoured the restoration of the original appearance of the turquoise, revealing a combination of blue-green tones and recovering the characteristic sheen through polishing and assembly. With the restructuring of the 
assembly system, the delicacy in the shape of the mosaic design and the luminosity due to the combination of colours, sheens, contours and angles of the tesserae were recovered. It is surprising that each of the artefacts recovered the sophistication and beauty of a luxury article, which means the reintegration of their essence as jewellery.

It should be noted that the removal of the mosaics from the walnut shell rings revealed technological features that, although not always easily accessible in the preview of the final assembly, provide aesthetic or complex functional effects that need to be discussed at more depth in the conclusion.

\section{DISCUSSION AND CONCLUSIONS}

During the development methodology of archaeological conservation, and particularly the approach to the rings with turquoise applications, new observations on their production came to light. It was found that they not only posed new areas of study on the technology of the artefacts, but also on the turquoise phenomenon, which deserve to be mentioned here and need to be studied in more depth, starting with a well-planned research agenda. For analytical reasons, these lines of research will be divided into four sections: bases, tesserae, adhesives and types of assembly.

\section{Bases}

Recent studies of turquoise artefacts have explored the nature of the organic bases used for their manufacture (MCEWAN et al. 2006; MEEHAN AND MAGAR, 
2012; STACEY et al., 2010), paying special attention to the identification of wood species. The rings discovered in the ZAAV offer a new, alternative base, which is unique, and which had not been reported on up until now: the pecan shell. The procurement of this material is of great interest since there are numerous botanical, archaeological, ethno-historical and historical studies about the pecan, Carys illionesis, although these studies are restricted to North America (HALL, 2000; ARSH et al., 1972; CHADDERDON, 1983; HESTER, 1978; HODGE, 1959; JACKSON, 1989; SMITH, 1953; STYLES et al., 1983; PICHARDO, 1931; WOLSTENHOLME, 1979).

A point worth mentioning is the current distribution of native species, which includes a large area of the southern states of Illinois, Iowa, Ohio, Kentucky, Alabama and Texas in the United Sates with isolated or "disjunctive" populations in Mexico, which has been the subject of debate regarding the role humans may have played in introducing them to these remote areas (HALL, 2000; MANNING, 1962). Although some authors like Thompson and Grauke (1991) have suggested that pecan populations in Mexico are native, records on its distribution in our country do not mention Zacatecas (MANNING, 1962), although it is notable that the extension and number of plantations have suffered a considerable reduction since the arrival of Europeans to North and Central America (HALL, 2000). This obviously raises new questions on the origin, procurement and possible trade routes of the pecan to produce the artefacts found in Alta Vista. Although it is difficult to establish the distribution of the pecan since it is only possible to distinguish its 
genus, which also includes chicory, there is evidence of its discovery in archaeological sites in Texas and Louisiana from as far back as 6750 B.C (HESTER, 1978; CHADDERDON, 1983; STYLES et al., 1983). The name Pecan, which comes from the indigenous Algonquian language (HODGE, 1959), indicates its extensive use by various native populations of the United States, from which we have several records of its use as food due to its high nutritional content, its long storage capacity of up to six months and its high productivity (HALL, 2000).

However, as far as I know, there are no records of its use as material for producing artefacts during the pre-Hispanic period in the United States. This absence seems to extend to principal ethnohistorical and ethnobotanical sources regarding indigenous populations of Central Mexico (SAHAGÚN, 1956; HERNÁNDEZ, 1959; NAVARRO, 1992), although this could be because Europeans were familiar with other nuts and considered the pecan to be just another variety, which was not worthy of further attention. An example of this is recorded in Vocabulario de Lengua Castellana y Mexicana, produced in New Spain by Alonso de Molina (1944) in the $16^{\text {th }}$ century, which says "the nut is a familiar fruit, the same".

Therefore, the use of nuts as a base for turquoise tesserae needs to be studied further not only from the ethnohistorical point of view, but also from a ethnographical and archaeological perspective, particularly regarding the production of rings, which are adapted to different thicknesses due to their flexibility to fit the size of the wearer's fingers, which raises questions on the extent of satisfaction of market demand. 


\section{Tesserae}

Studies on pre-Hispanic turquoise artefacts have focused predominantly on the identification of minerals to approach the theme of procurement and trade (MELGAR, 2010; WEIGAND, 1968; 1978; HARBOTTLE AND WEIGAND, 1992; MCEWAN ET AL., 2006; HULL AND FAYEK, 2012). The forum that we are attending today has realized the importance of the debates involving the turquoise phenomenon in the understanding of the pre-Hispanic past. Given the current progress in shaping the included debates, as well as the technological development of analysis techniques, particularly those of a non-destructive nature (MELGAR, 2010; HULL AND FAYEK, 2012; VELÁZQUEZ et al., 2012), it is necessary to work on the identification of the blue-green minerals which make up the objects being studied, particularly in virtue of the role Alta Vista plays in the development of the turquoise phenomenon in the interaction of the Mesoamerican cultures with those from the Southern United States.

It is important to consider here some of the observations derived from the archaeological conservation work carried out in the MUSZAV that permitted us to recognize indicative characteristics of the complexity of producing the artefacts, as well as the quality of their final result. An obvious characteristic is the high degree of polishing of the tesserae, a process that needs to be re-examined before the access of walnut shells, material that once pulverized, can be used as an abrasive.

Another evident characteristic was the delicate and perfect union of the tesserae in the rings, which is said to practically be a perfect fit on the front side, but which 
reveals oblique angles on the back. This detail, which initially appeared to be contrary to the logical stabilization of the mosaic to the base, could be a technological resource that allowed the tesserae to have a certain flexibility of movement with respect to the flexibility of the walnut shell base, facilitating its use and its adaptability to different thicknesses to fit the size of the wearer's finger. Of course, this flexibility of the tesserae implies questions on the use of the cutting tools, as well as the adhesive materials used.

\section{Adhesives}

Recent studies on artefacts made of turquoise and other semi-precious minerals have dealt with the identification of adhesives (FILLOY, 2010; 2012; STACEY et al., 2010; VELÁZQUEZ et al., 2012; MEEHAN AND MAGAR, 2012), concluding that they were resin based compounds used to join the tesserae to the base and to balance out the empty spaces derived from the thickness and assembly of the tesserae. The technological and functional considerations of the walnut shell rings from the AVAM referred to above, raise questions on the selection of adhesives, particularly regarding their properties of plasticity. Although during the disassembly, remains of the original adhesive could be observed, which upon contact with solvents recovered their viscosity (which suggests the use of resins), samples for analysis were not taken due to the high risk of contamination with the polymer used in the first intervention. This, however, makes it necessary to analyse untreated analogue materials and carry out experimental archaeological studies, which include resins mixed with Chia oil, an oily derivative from the pecan that has 
been reported ethnohistorically in the production and use at least with food for native populations of the United States (HALL, 2000).

\section{Assembly}

Several studies have provided evidence on the complexity of the techniques of assembling the tesserae used in turquoise mosaic pieces produced on various bases, which clearly show the technological sophistication involved in the development of a program of aesthetic and symbolic composition ( MCEWAN et al., 2006; FILLOY, 2012; KING et al., 2012; MEEHAN AND MAGAR, 2012; VELÁZQUEZ et al., 2012). The "turquoise" artefacts from Alta Vista need to be studied from these perspectives into a vision that integrates functional aspects. The assembly techniques for jewellery are exceptional, especially for rings, with respect to the use of flexible bases.

Finally, I would like to mention that there is no doubt that the last 25 years have witnessed important advances on the subject of the turquoise phenomenon from a purely archaeological approach. Recently, archaeological conservation has approached technological, functional, aesthetic and symbolic aspects as part of the value assessment exercises, which in turn are used to understand tangible and intangible variables of alteration to determine the decision-making and its implementation (FILLOY, 2012; KING et al., 2012; MEEHAN AND MAGAR 2012; VELÁZQUEZ et al., 2012). 
The collection of turquoise artefacts from the MUSAV is still in the process of being researched. However, during the development of the conservation methodology, particularly in the value assessment, diagnosis and intervention phases, a series of characteristics were discovered and used to explore in more depth topics widely studied by other disciplines, and hence propose new questions. These guidelines should be included in an integrated interdisciplinary vision in which archaeological conservation confirms its contribution to approach and understand the pre-Hispanic world starting with concrete physical evidence, whose complexity and beauty continue to be admired by us today.

\section{REFERENCES}

ARSH, N., R. FORD, and ARSH. 1972. Paleoethnobotany of the Kester Site. The Archaic Horizons. Springfield: Illinois State Museum.

Australian/ICOMOS, 1987. The Australian ICOMOS Charter for the conservation of places of cultural significance (The Burra Charter); Guidelines to the Burra Charter: cultural significance; Guidelines to the Burra Charter: conservation policy. Sydney, N.S.W.: Australia/ICOMOS.

AVECILLA, J., and M. FLORES. 2010. Práctica De Conservación Arqueológica En La Zona Arqueológica De Alta Vista, Zacatecas. México: ENCRyM-INAH.

AVECILLA, J., M. Flores, K. MARTÍNEZ, and A. SOTO. 2009. Informe De Los Trabajos De Conservación Realizados En El Museo De Sitio De La Zona Arqueológica De Alta Vista, Zacatecas, Noviembre 2009. México: ENCRyM-INAH.

CHADDERDON, M. F. 1983. Baker Cave, Val Verde County, Texas: the 1976 excavations. San Antonio: Center for Archaeological Research, University of Texas at San Antonio. 
FILLOY Nadal, L. 2010. Misterios de un rostro maya: la máscara funeraria de K'inich Janaab' Pakal de Palenque. México: Instituto Nacional de Antropología e Historia.

FILLOY Nadal, L. 2012. Mineralogy and Manufacturing Technique in a Group of Archaeological. In C. McEwan, C. Cartwright, and M. Carocci (eds.). Turquoise in Mexico and North America. London: Archetype Books.

GARCÍA Uranga, B., and H. MEDINA González. 2009. Inventario De Objetos Arqueológicos Del Museo De Sitio De Alta Vista, Zacatecas. Zacatecas. Centro INAH Zacatecas.

HALL, Grant. 2000. "Pecan Food Potential in Prehistoric North America". Economic Botany 54, 103-112.

HARBOTTLE, G., and P. C. WEIGAND. 1992. Turquoise in Pre-Columbian America. Scientific American 266(2): 78-84.

HERNÁNDEZ, F. 1959. Obras Completas, vol.2. México: Universidad Nacional Autónoma de México.

HESTER, T. R. 1978. Early human occupations in south central and southwestern Texas: preliminary papers on the Baker Cave and St. Mary's Hall sites. San Antonio: Center for Archaeological Research, University of Texas at San Antonio.

HODGE, F. W., (ed.). 1959. Handbook of American Indians North of Mexico in Two Parts: Part 2. Reprint Edition. Washington: Pageant Books, New York.

HULL, S., and M. FAYEK. 2012. "Cracking the Code of Pre-Columbian Turquoise Trade Networks and Procurement Strategies". In C. McEwan, C. Cartwright, and M. Carocci (eds.). Turquoise in Mexico and North America. London: Archetype Books, 29-40.

JACKSON, H. E. 1989. Poverty Point Adaptive Systems in the Lower Mississippi Valley : Subsistence Remains from the J. W. Copes Site. North American archaeologist 10(3): 173204.

KELLEY, C. 1974. Informe Preliminar Sobre Las Excavaciones y Estudios Relacionados 
Que Fueron Llebados a Cabo En El Sitio Arqueológico De Altavista (LCBJ3-1), Chalchihuites, Zacatecas y Áreas Adyacentes. Mrazo 10 a Junio 30, 1974. University of South of Illinois.

KELLEY, C. 1975. Preliminary Report on Excavations and Related Studies Carried Out at the Archeeological Site of Alta Vista, Chalchihuites, Zacatecas and in Adjacent Areas 1975. Carbondale: University of South Illinois, Carbondale.

KELLEY, C., and E. KELLEY. 1971. Informe Preliminar Para El Departamento De Monumentos Prehispánicos Del INAH Sobre Las Investigaciones Arqueológicas Llevadas a Cabo En El Monumento Alta Vista, Chalchihuites, Entre Octubre 25 y Diciembre 41971. Carbondale: University of South Illinois.

KING, J. C. H., C. CARTWRIGHT, and C. MCEWAN (eds.). 2012. Turquoise in Mexico and North America: Science, Conservation, Culture and Collections. Archetype Books.

MANNING, W. E. 1962. "Additional Notes on Juglans and Carya in Mexico and Central America". Bulletin of the Torrey Botanical Club 89 (2), 110.

MCEWAN, C., A. MIDDLETON, C. CARTWRIGHT, and R. STACEY, (eds.). 2006. Turquoise Mosaics from Mexico. London: Duke University Press Books.

MEDINA González, H., and B. GARCÍA Uranga. 2010. Altavista. A 100 Años De Su Descubrimiento. Mexico: INAH, Gobierno del Estado de Zacatecas.

MEDINA González, I. 2009a. Proyecto Para La Conservación Integrada Del Relieve Picacho Pelón. Zacatecas: ENCRyM-INAH.

MEDINA González, I. 2009b. Informe De La Primera Fase Del Proyecto De Conservación Integrada Del Relieve Picacho Pelón, Zona Arqueológico de Alta Vista, Zacatecas. México: Zacatecas: ENCRyM-INAH.

MEDINA González, I., and A. SANROMAN, 2009. Informe sobre la intervención de la colección del Museo de Sitio de Alta Vista. ENCRyM-INAH.

MEDINA González, I., and A. SANROMAN. 2011. La intervención de conservación sobre la colección arqueológica del Museo De Sitio de Alta Vista, Zacatecas. México: INAH.

MEEHAN, P., and V. MAGAR Meurs. 2012. Conservation of a Turquoise Mosaic Disk 
from Tula, Mexico. In C. McEwan, C. Cartwright, and M. Carocci (eds.). Turquoise in Mexico and North America. London: Archetype Books, 41-54.

MELGAR Tísoc, E. 2010. Una relectura del comercio de la turquesa: Entre Yacimientos, Talleres y Consumidores. In J. Long and A. Attolini (eds.). Caminos y Mercados De México. México, UNAM-INAH, 153-168.

MOLINA, A. 1944. Vocabulario De La Lengua Castellana y Mexicana, vol. 4. México: Ediciones de Cultura Hispánica.

NAVARRO, J. 1992. Historia Natural o Jardín Americano. México: Universidad Nacional Autónoma de México.

PEPPER, G. H. 1905. Ceremonial Objects and Ornaments from Pueblo Bonito, New Mexico. American Anthropologist 7 (2), 183-197.

PICHARDO, J. A. HACKETT, C. W. SHELBY, M. SPLAWN. 1931. Pichardo's Treatise on the Limits of Louisiana and Texas: an Argumentative Historical Treatise with Reference to the Verification of the True Limits of the Provinces of Louisiana and Texas. Austin: The University of Texas Press.

SAHAGÚN, B. 1956. Historia general de las cosas de Nueva España. México: Porrúa.

SANROMAN, A., J. AVECILLA, and M. FLORES. 2011. "Una Experiencia En La Conservación De Artefactos Arqueológicos: Práctica De Campo En El Museo De Sitio De Alta Vista, Zacatecas, Noviembre 2009". Intervención, Revista Internacional De Conservación, Restauración y Museología 2 (3), 66-73.

SMITH, J. R. 1953. Tree Crops : a Permanent Agriculture. New York: The Devin-Adair.

STACEY, R., C. CARTWRIGHT, and C. MCEWAN. 2010. Mastering Materials: Comparative Properties of Raw Materials on Turquoise Mosaics and Their Significance for Mosaic Technology. In C. McEwan, J. C. H. King, C. Cartwright, and M. Carocci, (eds.). Turquoise in Mexico and North America. London: Archetype Books, 7-14.

STYLES, B., S. AHLER, and M. FOWLER. 1983. Modoc Rock Shelter Revisited. In L. 


\section{Clio Arqueológica 2020, V35N2, p.190-222, GONZÁLEZ}

DOI: $10.20891 /$ clio.V35V2p190-222

PHILLIPS and J. BROWN (eds.). Archaic Hunters and Gatherers in the American Midwest. New York: Academic Press, 261-297.

THOMPSON, T. E., and L. GRAUKE. 1991. Pecans and Hickories (Carya). Acta Horticulturae XVIII, 839-904.

VELÁZZUEZ Castro, A., M. E. MARIN Benito, E. MELGAR Tisoc, R. SOLIS Ciriaco, and J. L. RUVALCABA Sil. 2012. "The Turquoise Disk from Offering 99 at the Templo Mayor in Tenochtitlan". In C. McEwan, C. Cartwright, and M. Carocci (eds.). Turquoise in Mexico and North America. London: Archetype Books, 75-87.

WEIGAND, P. C. 1968. The Mines and Mining Techniques of the Chalchihuites Culture. American Antiquity 33 (1), 45-61.

WEIGAND, P. C. 1978. The Prehistory of the State of Zacatecas, An Interpretation, Part I. Anthropology 2 (1), 66-87.

WEIGAND, P. C. 1993. Evolución de una civilización prehispánica: arqueología de Jalisco, Nayarit y Zacatecas. Zamora: El Colegio de Michoacán.

WOLSTENHOLME. B.N. 1979. Pecan Ecology. In G. R. McEarchern, (ed.). Texas Pecan Handbook. San Antonio: Department of Agriculture, 4-15. 